Edubiotik: Jurnal Pendidikan, Biologi dan Terapan

ISSN 2528-679X (print), ISSN 2597-9833 (online)

Vol. 6, No. 02, September 2021, pp. $99-107$

Available online at:

http://ejurnal.budiutomomalang.ac.id/index.php/edubiotik

Research Article

\title{
Literature study: Diversity level of coastal echinoidea as a source of biology learning materials for biodiversity
}

\author{
Muhamad Fahad AlFazali*, Yahya Hanafi, Destri Ratna Ma'rifah
}

Biology Education, Ahmad Dahlan University, Yogyakarta, Indonesia

Email: muhamad1600008141@webmail.uad.ac.id, yahya.hanafi@pbio.uad.ac.id, destrirm@pbio.uad.ac.id

\begin{tabular}{|c|c|}
\hline Article Information & ABSTRACT \\
\hline $\begin{array}{l}\text { Submitted: 2021-01-24 } \\
\text { Accepted: 2021-08-17 } \\
\text { Published: } 2021-09-18\end{array}$ & $\begin{array}{l}\text { The diverse learning resources around students' lives have not been optimally } \\
\text { utilized in learning. Learning resources are one of the important things in } \\
\text { improving the learning process, the surrounding environment can be used as an } \\
\text { effective and efficient learning resource because it provides a hands-on } \\
\text { experience to students. Learning activities that utilize the environment either } \\
\text { directly or not are biodiversity materials. Learning resources from the } \\
\text { surrounding environment are also expected to make students more sensitive and } \\
\text { easy to understand lessons. This study aims to determine the level of diversity of } \\
\text { Echinoidea in the intertidal zone and analyze the needs of learning resources. } \\
\text { The research method uses a literature study by searching for eight relevant } \\
\text { articles related to the level of diversity of Echinoidea in the coastal intertidal zone } \\
\text { on several accredited science journal websites as a source of study and then } \\
\text { reviewing and analyzing the requirements as a source of biology learning. This } \\
\text { study uses a narrative review design with the research instrument, namely the } \\
\text { researcher himself. The data analysis technique used descriptive analysis. The } \\
\text { results of the literature study showed that the diversity index of Echinoidea had a } \\
\text { moderate diversity index. The results of the analysis of potential needs for } \\
\text { learning resources that have been carried out show the results of research on } \\
\text { Echinoidea diversity meet the requirements as a source of study material for high } \\
\text { school biological diversity. } \\
\text { Keywords: Echinoidea; diversity; learning resources }\end{array}$ \\
\hline Publisher & How to Cite \\
\hline $\begin{array}{l}\text { Biology Education Department } \\
\text { IKIP Budi Utomo, Malang, Indonesia }\end{array}$ & $\begin{array}{l}\text { Alfazali, M. F., Hanafi, Y., \& Ma'rifah, D. (2021). Literature Study: Diversity level } \\
\text { of coastal echinoidea as a source of biology learning materials for biodiversity. } \\
\text { Edubiotik: Jurnal Pendidikan, Biologi Dan Terapan, 6(02), 99-107. https://doi.org/ } \\
\text { 10.33503/ebio.v6i02.1234 }\end{array}$ \\
\hline 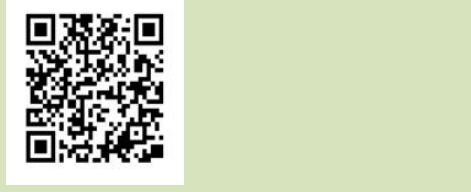 & $\begin{array}{l}\text { Copyright } \odot 2021 \text {, Alfazali et al. } \\
\text { This is an open access article under the CC-BY-SA license } \\
\text { cc) (i) (-) }\end{array}$ \\
\hline
\end{tabular}

\section{INTRODUCTION}

Various learning resources around students' lives have not been used optimally in learning (Supriadi, 2015). Learning resources are everything that contains messages conveyed through tools or by themselves or the messages are contained in the learning materials provided (Abdullah, 2012). While 
learning resources are everything that is designed or utilized both individually and collectively to help students learn (Sitepu, 2014).

Many biological learning resources potentially support the learning process and learning outcomes, one of which is the surrounding environment. The surrounding environment can be used as an effective and efficient learning resource because it will provide direct experience to students (Susilo, 2018). The fact is that most schools have not utilized the natural environment as a source of learning in their learning, especially the potential of learning resources in their respective areas. The use of locallybased learning materials and media is still limited to the school environment and has not utilized local potential. Most students consider it necessary to integrate local potential and wisdom in biology learning (Jayanti et al., 2017).

Based on the results of interviews with biology teachers at SMA N 5 Yogyakarta, the researcher knows that the school has not maximized the use of the environment as a learning resource. Learning resources that are more often used in the learning process are books and display pictures and videos related to the material to be taught. So that the learning of biology, especially the material on biodiversity, still does not utilize the surrounding environment as a learning resource. One source of biodiversity learning materials can be utilized from the surrounding environment, one of which is coastal ecosystems (Munajah \& Susilo, 2015). According to (Iskandar, 2015) in Indonesia, at least 47 ecosystems types have been recorded from the coast to the mountains. The coastal ecosystem itself is influenced by the daily cycle of tides. Organisms that live on the beach have structural adaptations so that they can be tightly attached to hard substrates. The middle of the beach is submerged at high tide and low tide. One of these areas is inhabited by the class Echinoidea which belongs to the phylum Echinoderms (Wijana, 2014).

Sea urchins belong to the class Echinoidea, one of five classes in the Phylum Echinoderms (Invertebrates) (Mistiasih, 2013). This animal is in the shape of a radial pentagon and its entire body is covered with thorns (Alwi et al., 2020). Its habitat is in the sea with a wide area so that it can be found on beaches that have rocky and sandy substrates in various parts of the world (Hartati et al., 2018). Organisms that live on the coast have structural adaptations so that they can cling to hard substrates. The middle area of the beach is submerged during high and low tides. This area is inhabited by the class Echinoidea included in the phylum Echinoderms (Wijana, 2014). Sea urchins have two phases in their life, namely the larval phase (bilateral symmetry), called pluteus, and the adult phase (radial symmetry) because the body is covered with spines. Sea urchin larvae are planktonic. The larvae will swim to follow the mass of water so that the distribution area becomes very wide. Sea urchins, like other invertebrates, are not very popular among the general public in Indonesia, although there have been many domestic and foreign studies studying their species and behavior.

In a previous study regarding the inventory of Echinoderms diversity on the Seupang beach as a biology learning medium to study the diversity of Echinoderms on Seupang Beach and compile a media booklet from the results of the Echinoderm diversity inventory (Lestari et al., 2020). In addition, previous research on species of sea urchins (Echinoidea) in the waters of Panjang Island, Central Bangka Regency, Bangka Belitung Province explained the Echinoidea species found in the region (Lubis et al., 2016). Previous research on echinoderms while researchers limit the discussion to the level of diversity of Echinoidea, the research done has not provided information until the stage of analyzing the requirements as a source of biology learning. Therefore, the purpose of this study was analyze the diversity index of Echinoidea and the need for biological learning resources based on research results from literature studies. 


\section{RESEARCH METHODS}

This research method uses a literature study about the level of diversity of Echinoidea in the coastal intertidal zone. This research was conducted during July - October 2020 at the UAD Biological Education Laboratory. The narrative review design is to focus the discussion, describe a variety of specific themes or topics. Research begins with a search of libraries relevant to the research topic. Scientific article search procedure is done by accessing official websites: www.schoolar.google.co.id, www.garuda.ristekdikti.go.id, www.sinta.ristekbrin.go.id, www.science.direct.go.id, www.lipi.go.id, www. rama.ristekbrin.go.id. Keywords used in the search for scientific articles are Echinoidea diversity, biological learning resources, biodiversity material.

The scientific articles used in this study amounted to 8 scientific articles and had met the criteria consisting of 8 accredited national journals. The researchers had been determined as many as eight journals because the 29 journals tell about Echinodermata, and the researchers only discussed Echinoidea. The instrument of this research is the researcher himself. The researchers used the data analysis techniques adopted from (Gregory \& Denniss, 2018): (1) Define Topic And Audience, which is determined to the topic of the problem. (2) Literature Search i.e. looking for articles relevant to the topic to be researched. (3) Be Critical, i.e. become critical when reading scientific articles that then summarize the relevant literature by analyzing and identifying the problem of studies that are reviewed in gaps. (4) Find A Logical Structure, which is to find a logical structure in the reviewed narrative by writing reviews directly and effectively.

The articles that have been reviewed are then analyzed using an analysis of learning resource requirements (Suhardi, 2012). For example, clarity of potential availability of objects and issues, conformity with a learning outcome, material objectives clarity and their allocation, information to be disclosed, exploration guidelines, and acquisitions to be achieved.

\section{FINDING AND DISCUSSION}

Based on the results obtained from 8 articles shows that the articles that fall into the category of diversity level Echinoidea is 8 , and no articles are classified as low and high. Scientific articles discussing the Echinoidea Class diversity index specifically consisting of 8 articles from accredited national journals, including research (Alwi et al., 2020) entitled Morphological Characteristics and Ecological Index Sea Urchins (Echinoidea) in Wawama Village Water Morotai Island District; (Purnomo et al., 2019) Community Structure and Distribution of Sea urchins (Echinoidea) in The Seagrass Field Area of Serangan Beach, Bali; (Noviana et al., 2019) Distribution and Abundance of Sea urchins (Echinoidea) in the Waters of Pasir Putih Island, Sumberkima Village, Buleleng, Bali; (Yudasmara, 2013) Diversity and Dominance of Sea urchin communities (Echinoidea) in the Waters of Menjangan Island, West Bali National Park; (Laning et al., 2014) Distribution Of Sea Urchin (Echinoidea) In The Seagrass Beds Of Merta Segara Beach, Sanur-Bali; (Wulandewi et al., 2015) Identify Species And Density Of Sea Urchin (Echinoidea) At Sanur And Serangan Beach, Denpasar- Bali; (Suryanti \& Ruswahyuni, 2014) The Difference in Abundance of Echinoideas on Coral Ecosystem and Seagrass Beds in Pancuran Belakang, Karimunjawa, Jepara; (Ristanto et al., 2017) Sea Urchin (Echinoidea) Distribution and Abundance in the Intertidal Zone of Bengkayang Regency. More details can be seen in Table 1.

Table 1. Echinoidea Diversity Index

\begin{tabular}{ccc}
\hline Research Locations & Diversity Index & Category \\
\hline AlFazali, et al. - Literature study: Diversity level of coastal echinoidea as a source of ... & 101
\end{tabular}




\begin{tabular}{ccc}
\hline Morotai Island & $H^{\prime}=1,009$ & Medium \\
Serangan Beach Bali & $H^{\prime}=1,50-1,59$ & Medium \\
Pasir Putih Island Waters & $H^{\prime}=1,162$ & Medium \\
Menjangan Island & $H^{\prime}=1,926$ & Medium \\
Merta Segara Beach, Sanur & $H^{\prime}=2,43$ & Medium \\
Sanur and Serangan beach & $H^{\prime}=1,66-2,23$ & Medium \\
Karimunjawa Pancuran Belakang & $H^{\prime}=1,054-1,279$ & Medium \\
Bengkayang Waters & $H^{\prime}=1,235$ & Medium \\
\hline
\end{tabular}

Based on Table 1 of the analysis of the index of the diversity of sea urchin species in the location of 8 research articles, it is seen that the value of the index of species diversity $\left(\mathrm{H}^{\prime}\right)$ is all classified as a moderate category. It happens because of the relatively large number of types of sea urchins and the proportion of high-density numbers that make up the community. Diversity is a difference that can be found in communities or groups of different species living somewhere (Purnomo et al., 2019). The diversity index on the study (Alwi et al., 2020) on Morotai island is said to be moderate because there is no competition between the types so high, the availability of sufficient food, and favorable environmental conditions. This is reinforced by research (Yudasmara, 2013) The moderate diversity index value (Suryanti \& Ruswahyuni, 2014) in the backwaters of Karimunjawa is due to the nature of sea urchins and the habitability of life in coral and sandy substrates. Another thing is assumed because in the location of seagrass fields there is still human activity both in catching fish and more tourism compared to coral ecosystems. The value of the diversity index $\left(\mathrm{H}^{\prime}\right)$ in water is influenced by the number of individuals and types of sea urchins found. According to (Radjab et al., 2014) in general, Echinoidea is often found in unspoiled waters. The condition of unspoiled waters in water is the normal condition of an environment.

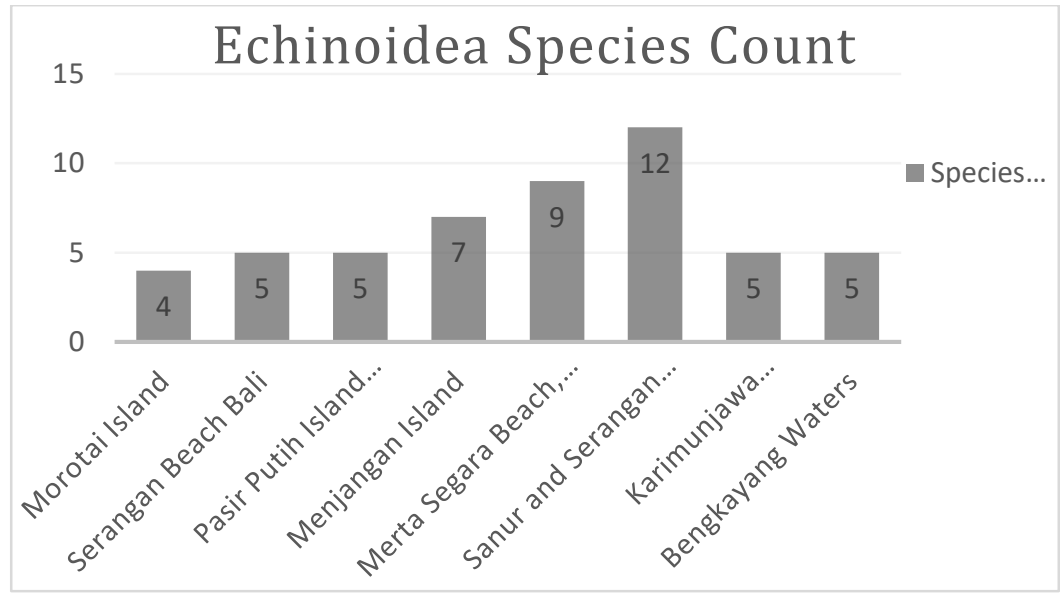

Figure 1. Figure Echinoidea Species Count Graph

Based on the data in Figure 1 shows that the number of Echinoidea species that are mostly found is in the waters of Sanur Beach and Serangan with the number of species found as many as 12 species of Echinoidea. This is because Echinoidea sampling is done on Merta Segara Beach and Mertasari beach there are many community activities, namely fishing activities and marine tourism such as swimming, snorkeling, fishing, and traditional sailboat services. Community activities can damage the structure of seagrass that becomes the habitat of sea urchins so that it can indirectly affect the density of the sea urchins. The large number of Echinoidea species found due to these waters has the condition of the basic substrate of sandy, muddy, and nesting sedimentary waters in the tubing area. It is 
according to the opinion (Hartati et al., 2018) that the habitat of sea urchins is found in seagrass areas and coral reefs, sandy areas, or muddy sand and is also obtained on shards of coral.

Common species include Diadema setosum and Echinometra mathaei. The species Diadema setosum was found in all research articles and Echinometra mathaei was found in 7 different articles. The species Diadema setosum can generally be found throughout coastal waters, from tidal areas to deep waters. Diadema setosum sea urchins in their habitat are herbivorous and grazer-type animals that live in groups (Wulandewi et al., 2015). Diadema setosum sea urchin prefers clear waters and relatively calm water (Thamrin et al., 2011). The large number of Diadema Setosum is thought to be influenced by the condition of aquatic habitats, where this species is found in rocky zones because it is influenced by food factors and how to eat (Thamrin et al., 2011). Rough substrate conditions strongly support the survival of Echinoidea species, especially Diadema Setosum (Ibrahim et al., 2017). This is following the statement (Rumahlatu, 2011) states that Diadema setosum is also tolerant of pollutants in aquatic areas, so its existence is classified as more abundant than other species. According to research (Moningkey, 2010) Echinometra mathaei lives on substrates of corals and rocks that aim to shelter from the tides of the sea and also attack predators. Echinometra mathaei sea urchins have a low-density level, as this breed generally lives hiding in holes in reefs or rocks (Juliawan et al., 2017).

Table 2. Learning Resource Requirement Analysis

\begin{tabular}{|c|c|c|c|}
\hline No & Learning Resource Requirements & Description & Information \\
\hline 1 & $\begin{array}{c}\text { Clarity of potential availability of objects } \\
\text { and issues raised }\end{array}$ & $\begin{array}{l}\text { The clarity of the potential availability of objects is the } \\
\text { Echinoidea class. The issue that will be raised is the } \\
\text { level of diversity of Echinoidea }\end{array}$ & Conform \\
\hline 2 & Conformity with learning objectives & $\begin{array}{l}\text { The learning objectives in KD } 3.2 \text { are: Describing the } \\
\text { diversity of species and ecosystems, describing } \\
\text { biodiversity in Indonesia, grouping different types of } \\
\text { living things at the type and ecosystem level of } \\
\text { various objects, looking for data on the threat of } \\
\text { sustainability of various Indonesian animal diversity } \\
\text { and compiling the results in the form of reports }\end{array}$ & Conform \\
\hline 3 & $\begin{array}{c}\text { Clarity of material objectives and their } \\
\text { designations }\end{array}$ & $\begin{array}{l}\text { Material targets have reached the level of species } \\
\text { and ecosystem diversity as well as biodiversity } \\
\text { threats. Biodiversity materials intended for high } \\
\text { school students in grade X }\end{array}$ & Conform \\
\hline 4 & Clarity of information to be disclosed & $\begin{array}{l}\text { Information revealed: Types of Echinoidea, diversity } \\
\text { of Echinoidea species and ecosystems and threats }\end{array}$ & Conform \\
\hline 5 & Exploration guidelines & $\begin{array}{l}\text { Field research procedures are: determination of } \\
\text { research objects, observations, transect squares } \\
\text { method, use of tools and materials, how it works, } \\
\text { data analysis, and conclusion drawing }\end{array}$ & Conform \\
\hline 6 & Gain to be achieved & $\begin{array}{l}\text { Following the learning objectives that have been } \\
\text { achieved at the diversity of types, ecosystems, and } \\
\text { threats }\end{array}$ & Conform \\
\hline
\end{tabular}

Table 2 shows that the results of the research obtained then analyzed the potential requirements as a source of biological learning according to (Suhardi, 2012) are as follows:

1. Clarity of potential availability of objects and issues raised

The object used in this study was Echinoidea species found as many as 19 species found at the research site with different substrate types. Common species of Echinoidea are Diadema setosum, Echinometra mathaei and Echinotrix calamaris. Diadema setosum is one of the Echinoidea species that inhabits the most coral reefs, sandy areas, and rocky areas so it is easy to find and scatter in all aquatic areas (Arhas et al., 2015). The species is mostly found in locations with rocky substrates, shards of 
coral, sandy, muddy, and seagrass. The Echinoidea diversity index in the article has a moderate category. The problem raised based on the results of the study is the diversity of Echinoidea found in 8 articles with different research locations. The Echinoidea species were found to have different species and 8 articles had research sites with different substrate types per location. It will provide students with information on examples of species and ecosystem diversity.

2. Conformity to learning objectives

Conformity in question is the result of research with basic competencies listed based on the 2013 curriculum, namely KD 3.2 analyzing various levels of biodiversity in Indonesia and its threats and preservation with the subject matter of biodiversity that includes the diversity of types and ecosystems. The results of the study are following the purpose of learning on biodiversity materials, namely (1) explaining the concept of species diversity, and ecosystems; (2) describe biodiversity in Indonesia; (3) group different types of living things at the type level, and ecosystems; (4) analyze the threat of environmental damage and conservation efforts to biodiversity. Based on the results, the results show that the research has achieved the objectives of learning type-level biodiversity, ecosystem-level biodiversity, and threats to biodiversity sustainability.

3. Material Goals and Their Designations

Material goals in this study (object) is the diversity of Echinoidea in the coastal intertidal zone where biodiversity material is one of the biological learning materials in high school. The subject of this study is high school students' class X. Biodiversity material is high school biology material. The subject matter presented in KD 3.2 is the biodiversity level, biodiversity in Indonesia, classification of living things, threats, and efforts to conserve biodiversity. The subject matter of biodiversity level is divided into sub-materials namely genes, types, and ecosystems. Based on the clarity of material objectives, the results of this study have met the material diversity of types, ecosystems, and threats to diversity.

4. Information disclosed

This research shows that there is a level of diversity in Echinoidea namely the level of type and ecosystem. In addition, there is also biodiversity in Indonesia as well as threats that can interfere with the sustainability of biodiversity levels in the environment based on eight articles used. The fact obtained from the review of 8 articles is that the category of diversity level of Echinoidea class contained in the article is all medium category. Furthermore, there are 19 types of Echinoidea among them: Diadema setosum, Diadama savignyi, Diadema palmeri, Echinometra mathaei, Echinometra virdis, Echinotrix calamaris, Echinotrix diadema, Tripenustes gratilla, Brissus latecarinatus, Toxonopsus pileolus, Salmacis belli, Pseudobolatia maculata, Mespilia globulus, Astropyga radiata, Maretia planulata, Echinocardium sp., Clypeaster sp., Heterocentrocus trigonarius, and Temnopleurus alexandri. Another fact in this study is the characteristics of habitat found in some studies, namely Echinoidea habitat. It can be found in various substrates such: as sandy, muddy, coral reefs, shards of coral, and dead corals. Sea urchins are herbivorous animals because The diet of sea urchins generally eats algae found on coral reefs. Sea urchins have a physical defense (spines) that make this organism suitable to survive and protect itself from marine organisms (Noviana et al., 2019).

\section{Exploration guidelines}

There are several working steps contained in the article to conduct research, including the determination of research objects, conducting site surveys, determining the study area, determining the methods used (the transect squares method), preparing tools and materials, how it works, data processing, and the latter concluding.

6. Gain to be achieved 
The clarity to be achieved is based on the learning objectives to be achieved. Based on KD 3.2, which analyzes various levels of biodiversity in Indonesia and its threats and conservation, the research results have fulfilled some of the learning objectives to be achieved as well as the scope of biodiversity materials. The acquisition that will be achieved by this study has fulfilled the objectives of learning biodiversity at the level of species and ecosystems as well as the threat of biodiversity.

This is following previous research regarding the analysis of the potential of the surrounding environment as an efficient source, it was found that before the potential of the environment will be used as a learning resource, educators must go through several stages as a process of making learning resources (Susilo, 2018). In addition, research on the use of the environment as a learning resource to increase the interest and learning outcomes of high school students in the Coastal Region of South Kalimantan explained that learning by utilizing the environment as a learning resource received a positive response from students with a percentage score of $85.5 \%$ (school A), and $87.5 \%$ (school B). The average student interest response score was $86.5 \%$ (positive). This learning can improve students' cognitive learning outcomes with an average $\mathrm{N}$-gain of 0.42 (medium) for school $\mathrm{A}$ students, and an average N-gain of 0.79 (high) for school B students (Irwandi \& Fajeriadi, 2019). This shows that the surrounding environment can be used as a learning resource that can improve student learning outcomes.

Other studies also explain that the environment can be used as a natural laboratory in science learning in Primary school. The environment which is learning objectives, resources, and facilities can be used as a place to do practice, demonstration, experiment, research, and taking knowledge in the process of science learning. By making use of the environment as a natural laboratory in pro-science learning sessions, it is expected that students will obtain information based on experience directly and can learn from the things that concrete so that it will be easier for students to understand the material and learning experience more meaningful by students (Utaminingsih, 2015).

\section{CONCLUSION}

The results of the review of 8 articles, found 19 species of the Echinoidea class by showing that the diversity index belongs to the moderate category. Based on the analysis of the requirements as a source of biological learning conducted get the results that this study qualifies as a source of biology learning high school Class $X$ biodiversity material. The process of learning biology students using the environment, due to the limitations of researchers to conduct direct research, the results of this literature study can improve student understanding, students are active in participating in learning, discussing the material presented, forming groups to complete assignments, improving students' ability to communicate verbally such as discussions, presentations, and conduct questions and answers about biodiversity, especially Echinoidea.

\section{ACKNOWLEDMENT}

Thanks are conveyed to colleagues who have helped a lot in carrying out the research and the supervisors who have provided direction and input for this research.

\section{REFERENCES}

Abdullah, R. (2012). Pembelajaran berbasis pemanfaatan sumber belajar. Jurnal IImiah DIDAKTIKA, XII(2), 216-231. https://doi.org/http://dx.doi.org/10.22373/jid.v12i2.449

Alwi, D., Muhammad, S. H., \& Tae, I. (2020). Karakteristik morfologi dan indeks ekologi bulu babi 
(Echinoidea ) di Perairan Desa Wawama Kabupaten Pulau Morotai. Jurnal Sumberdaya Akuatik Indopasifik, 4(1), 23-32. https://doi.org/10.46252/jsai-fpik-unipa.2020.Vol.4.No.1.95

Arhas, F. R., Mahdi, N., \& Kamal, S. (2015). Struktur komunitas dan karakteristik bulu babi (Echinoidea) di zona sublitoral perairan iboh kecamatan Sukakarya kota Sabang. Prosiding Seminar Nasional Biotik, 233-238. https://jurnal.ar-raniry.ac.id/index.php/PBiotik/article/view/2691

Gregory, A. T., \& Denniss, A. R. (2018). An introduction to writing narrative and systematic reviews tasks, tips and traps for aspiring authors. Heart Lung and Circulation, 27(7), 893-898. https://doi.org/10.1016/j.hlc.2018.03.027

Hartati, R., Meirawati, E., Redjeki, S., Riniatsih, I., \& Mahendrajaya, R. T. (2018). Jenis-jenis bintang laut dan bulu babi (Asteroidea, Echinoidea: Echinodermata) di perairan pulau Cilik, kepulauan Karimunjawa. Jurnal Kelautan Tropis, 21(1), 41. https://doi.org/10.14710/jkt.v21i1.2417

Ibrahim, I., Devira, C. N., \& Purnawan, S. (2017). Struktur komunitas Echinoidea (bulu babi) di perairan pesisir pantai teluk Nibung kecamatan pulau Banyak kabupaten Aceh Singkil. Prosiding Seminar Nasional Biotik, 193-198. https://jurnal.ar-raniry.ac.id/index.php/PBiotik/article/view/2145/1598

Irwandi, \& Fajeriadi, H. (2019). Pemanfaatan Lingkungan sebagai sumber belajar untuk meningkatkan minat dan hasil belajar siswa SMA di kawasan Pesisir, Kalimantan Selatan. BIO-INOVED : Jurnal Biologi-Inovasi Pendidikan, 1(2), 66-73. https://doi.org/http://dx.doi.org/10.20527/binov.v1i2.7859

Iskandar, J. (2015). Keanekaragaman hayati jenis binatang: Manfaat ekologi bagi manusia. Graha IImu. http://library.fmipa.uny.ac.id/opac//index.php?p=show_detail\&id=13513

Jayanti, U. N. A. D., Susilo, H., \& Suarsini, E. (2017). Analisis kebutuhan bentuk sumber belajar dan media pembelajaran biologi berbasis potensi lokal untuk kelas x SMA di provinsi Lampung. Pros. Seminar Pend. IPA Pascasarjana UM, 591-599. http://pasca.um.ac.id/conferences/index.php/ipa 2017/article/view/1122/788

Juliawan, Dewiyanti, I., \& Nurfadillah. (2017). Kelimpahan dan pola sebaran bulu babi (Echinodea) di perairan pulau Klah kota Sabang. Jurnal IImiah Mahasiswa Kelautan Dan Perikanan Unsyiah, 2(November), 541-546. http://jim.unsyiah.ac.id/fkp/article/view/7777

Laning, T. H., Yusup, D.S., \& Wiryatno, J. (2014). Sebaran bulu babi (Echinoidea) di kawasan Padang Lamun Pantai Merta Segara, Sanur-Bali. Jurnal Biologi, 18(2), 41-45. https://doi.org/1410-5292

Lestari, Y., Munarti, \& Kurniasih, S. (2020). Inventarisasi keanekaragaman echinodermata di pantai Seupang sebagai media pembelajaran biologi. Journal of Biology Education Research, 1(1), 3339. https://doi.org/10.3375/jber.v1i1.2634

Lubis, S. A., Purnama, A. A., \& Yolanda, R. (2016). Spesies bulu babi (Echinoidea) di perairan pulau Panjang kabupaten Bangka Tengah provinsi Bangka Belitung. Prosiding Seminar Nasional Biotik, 1. https://media.neliti.com/

Mistiasih, W. D. (2013). Struktur dan sebaran komunitas bulu babi (Echinoidea) di habitat lamun pulau Sapudi, kabupaten Sumenep, Madura. SKRIPSI. https://repository.ipb.ac.id/handle/123456789 161386

Moningkey, R. D. (2010). Pertumbuhan populasi bulu babi (Echinometra mathaei) di perairan pesisir Kima Bajo kabupaten Minahasa Utara. Jurnal Perikanan Dan Kelautan Tropis, 6(2), 73. https://doi.org/10.35800/jpkt.6.2.2010.164

Munajah, \& Susilo, M. J. (2015). Potensi sumber belajar biologi SMA kelas x materi keanekaragaman tumbuhan tingkat tinggi di kebun binatang Gembira Loka. JUPEMASI-PBIO, 1(2), 2010-2013. http://jupemasipbio.uad.ac.id/

Noviana, N. P. E., Julyantoro, P. G. S., \& Pebriani, D. A. A. (2019). Distribusi dan kelimpahan bulu babi ( Echinoidea ) di perairan pulau Pasir Putih, desa Sumberkima, Buleleng, Bali. Current Trends in Aquatic Science, 2(1), 22-29. https://ojs.unud.ac.id/index.php/CTAS/article/view/42514/30170

Purnomo, I. G. P. A., Dharma, I. S., \& Putra, I. N. G. (2019). Struktur komunitas dan sebaran bulu babi (Echinoidea) di kawasan padang lamun pantai Serangan, Bali. JMRT, 2(2), 29-33. https://doi.org/https://doi.org/10.24843/JMRT.2019.v02.102.p06

Radjab, A. W., Rumahenga, S. A., Soamole, A., Polnaya, D., \& Barends, W. (2014). Keragaman dan 
kepadatan ekinodermata di perairan Teluk Weda, Maluku Utara. Jurnal IImu Dan Teknologi Kelautan Tropis, 6(1), 17-30. https://doi.org/https://doi.org/10.29244/jitkt.v6i1.8624

Ristanto, A., Yanti, A. H., \& Setyawati, T. R. (2017). Komposisi jenis bulu babi (kelas: Echinoidea) di daerah intertidal pulau Lemukutan kabupaten Bengkayang. Protobiont, 6(1), 59-63. https://doi.org/http://dx.doi.org/10.26418/protobiont.v6i1.18158

Rumahlatu, D. (2011). Konsentrasi logam berat kadmium pada air, sedimen dan Deadema setosum (Echinodermata, Echinoidea) di perairan pulau Ambon. IImu Kelautan, 16(2), 78-85. https://doi.org/https://doi.org/10.14710/ik.ijms.16.2.78-85

Sitepu, B. P. (2014). Pengembangan sumber belajar. Rajawali Pers. https://opac.perpusnas.go.id/ DetailOpac.aspx?id=912340

Suhardi. (2012). Pengembangan sumber belajar biologi. UNY Press. https://onesearch.id/Record/ IOS4965.018197

Supriadi. (2015). Pemanfaatan sumber belajar dalam proses pembelajaran. Lantanida Journal, 3(2), 127-139. https://doi.org/http://dx.doi.org/10.22373/lj.v3i2.1654

Suryanti, \& Ruswahyuni. (2014). Perbedaan kelimpahan bulu babi (Echinoidea) pada ekosistem karang dan lamun di Pancuran Belakang, Karimunjawa Jepara. Jurnal Saintek Perikanan, 10(1), 62-67. https://doi.org/10.14710/ijfst.10.1.62-67

Susilo, M. J. (2018). Analisis potensi lingkungan sekitar sebagai sumber belajar biologi yang berdayaguna. Proceeding Biology Education Conference, 15(2017), 541-546. https://jurnal.uns. ac.id/prosbi/article/view/32606/21596

Thamrin, Setiawan, Y., \& Siregar, S. (2011). Analisis kepadatan bulu babi Diadema Setosum pada kondisi terumbu karang berbeda di desa Mapur kepulauan Riau. Jurnal IImu Lingkungan, 5(1), 4553. https://doi.org/ttp://dx.doi.org/10.31258/jil.5.01.p.45-53

Utaminingsih, R. (2015). Pemanfaatan lingkungan sebagai laboratorium alam pada pembelajaran IPA SD. Trihayu: Jurnal Pendidikan Ke-SD-An, 2(1), 215-220. https://doi.org/10.30738/trihayu.v2i1 .792

Wijana, N. (2014). IImu lingkungan (2nd ed.). Graha IImu. https://opac.perpusnas.go.id/DetailOpac.as px?id $=935925$

Wulandewi, N. L. E., Subagio, J. N., \& Wiryatno, J. (2015). Jenis dan densitas bulu babi (Echinoidea) di kawasan pantai Sanur dan Serangan Denpasar- Bali. Jurnal Simbiosis, 3(1), 269-280. https://ojs. unud.ac.id/index.php/simbiosis/article/view/14406/9902

Yudasmara, G. A. (2013). Keanekaragaman dan dominansi komunitas bulu babi (Echinoidea) di perairan pulau Menjangan kawasan Taman Nasional Bali Barat. Jurnal Sains Dan Teknologi, 2(2), 213-220. https://doi.org/http://dx.doi.org/10.23887/jst-undiksha.v2i2.2897 